\title{
The quiet Portuguese: Are Portuguese taxpayers victims of fiscal illusion?
}

\author{
Ana Araujo ${ }^{a}$ Paulo Jorge Reis Mourão*b / Pedro Daraujo1c \\ a University of Minho - Department of Economics - Portugal \\ b University of Minho - Department of Economics \& NIPE - Portugal \\ c University of São Paulo - Brazil / University of Munster-WWU - Germany
}

Received: 17 February 2020 / Accepted: 10 May 2020

\begin{abstract}
This article discusses the four dimensions generating fiscal illusion through a survey answered by a sample of the population of the northern region of Portugal. These dimensions were (1) bias in the taxpayers' perception of the costs and benefits of public programs; (2) ignorance or inattention to fiscal reality (e.g. tax structure or associated collection); (3) taking advantage of the taxpayer's timing and expectations for an optimized tax collection; and (4) association of the surrounding socioeconomic reality with the tax structure. The results show that the most serious dimension present among the analyzed Portuguese taxpayers is the relative lack of attention to fiscal reality. Through an analysis using appropriate tests, it was observed that some dimensions, such as education and taxpayer income, significantly influence the individual risk of fiscal illusion.
\end{abstract}

\section{Keywords}

Fiscal illusion / Tax illusion / Portugal / Population surveys / Income.

\section{Os portugueses tranquilos: son os contribuíntes portugueses víctimas da ilusión fiscal?}

\section{Resumo}

Este artigo analiza as catro dimensións que xeran ilusión fiscal a través dunha enquisa respondida por unha mostra da poboación da rexión norte de Portugal. As dimensións enquisadas foron: (1) nesgo na percepción dos contribuíntes dos custos e beneficios dos programas públicos; (2) ignorancia ou falta de atención sobre a realidade fiscal (como sobre a estrutura tributaria ou a recadación asociada); (3) aproveitar o calendario e as expectativas do contribuínte para unha recadación de impostos optimizada; e (4) asociación da realidade socioeconómica circundante coa estrutura fiscal. Os resultados mostran que a dimensión máis grave presente entre os contribuíntes portugueses analizados é a relativa falta de atención á realidade fiscal. A través dunha análise utilizando probas apropiadas, observouse que algunhas dimensións, como a educación e os ingresos dos contribuíntes, inflúen significativamente no risco individual de ilusión fiscal.

\section{Palabras clave}

Ilusión fiscal / Portugal / Enquisas de poboación / Ingresos.

Códigos JEL: H30, H89, C83.

\footnotetext{
* Corresponding author: paulom@eeg.uminho.pt

1 The authors acknowledge the contributions provided by two anonymous reviewers of Revista Galega de Economía. Remaining limitations are authors' exclusive ones. Pedro Daraújo also acknowledges the following: This work was supported by a grant from the Brazil Centre of the University of Münster, under the auspices of the German Academic Exchange Service (DAAD) and the German Federal Ministry of Education and Research. Paulo Mourão acknowledges the following: This paper is financed by National Funds of the FCT - Portuguese Foundation for Science and Technology within the project UIDB/03182/2020.
} 


\section{Introduction}

The phenomenon of fiscal illusion is present whenever taxpayers do not realize how much they are actually pay for the public services they acquire and how much the state receives for the same acquisition. Tax perceptions have been studied since the early twentieth century and attempts through surveys have recently been made to measure the level of fiscal illusion for certain countries. Fiscal illusion has serious socioeconomic and political consequences, such as distortions in budget aggregates, impact on a country's economic development, or even growing distrust between the state and its citizens.

The purpose of this work is to investigate the taxpayers' perception of taxes in a sample of the northern Portuguese population and to contribute to the detailed study of the fiscal illusion in the Portuguese area specially related to the four perspectives mentioned below.

From the launching of the theoretical hypothesis by Amilcare Puviani in 1903 to the methodological and conceptual diversity that has characterized the set of publications discussing the theme, we can recognize that the question of "fiscal illusion" has remained remarkably alive. This recognition is justified to the extent that the lack of a mainstream microeconomic rationale or even the difficulty of empirical proof of the phenomenon -as pointed out by Oates (1988)- did not lead to academic abandonment. On the contrary, authors such as Mauro Fasiani (1949), James Buchanan (1960) and Richard Wagner (1976) in earlier decades or more recently Sausgruber and Tyran (2005), Dell'Anno and Mourão (2012) have contributed to the topic.

Also, surveys conducted with the population have been found to be of particularly important. Some of the works in this line are those of Winter and Mouritzen (2001) and Sanandaji and Wallace (2010). As will be discussed, these works give a microeconomic approach to a reality that is often perceived or studied if restricted to the macroeconomic data approach. They also allow a certain return to the origins of the discussion about fiscal illusion, which has been specifically aimed at the living conditions of the population.

In the empirical investigation of this article, the methodology used was based on the collection and analysis of the responses to a survey distributed among a sample of the Portuguese population in the Northern Region. Through this methodology, we analyzed the level of tax perception and of fiscal illusion from a sample of the population from Northern Portugal composed of 349 random individuals.

From the responses collected from the survey, it was found that the majority of respondents (providing for a mean sample error of 5.2\%) manifest a predisposition to suffer from fiscal illusion, mainly through the dimension of a significant unawareness to fiscal reality.

The remainder of this work consists of four sections. Section 2 revisits the main lines of the development of fiscal illusion. It summarizes this development along four main lines: (1) bias in the perception of the costs and benefits of public programs by taxpayers; (2) ignorance or inattention to fiscal reality (tax structure, associated collection, etc.); (3) advantage of the taxpayer's timing and expectations for tax collection; and (4) association of the surrounding socioeconomic reality with the tax structure. Section 3 describes the main steps in the distribution and completion of the survey by a sample of the Portuguese population, concentrated in the northern region of the country. This section will also detail the methodological steps behind this original effort for Portugal. Section 4 concludes, introducing policy implications and emphasizing some of the most stimulating challenges derived from this research.

\section{Fiscal illusion: Theoretical problem or hard reality?}

The study of fiscal illusion is not particularly recent in public finance literature. However, in recent decades, it has gained more prominence in the global movement for the implementation of greater tax transparency. 
However, it was with the late nineteenth-century Italian financier Amilcare Puviani (1903) that the analysis of fiscal illusion obtained its first systematic study. Since then, the literature on Fiscal Illusion has developed in many directions - from developments that sought a mathematical basis and microeconomic modeling to works of empirical validation or bibliometric reflection. Thus, there is a significant body of work on fiscal illusion. The Web of Science database contained (as November 2019) 255 papers and the Scopus database contained 210 publications with the terms 'fiscal illusion' in the title, in the abstract, or among the keywords.

For the purposes of this article, we will structure the various illusory strategies according to four specific groups discussed by Sausgruber and Tyran (2005), Sanandaji and Wallace (2010), or Dell'Anno and Mourão (2012): (1) bias in the taxpayers' perception of the costs and benefits of public programs; (2) ignorance or inattention to the fiscal reality; (3) the advantage of the taxpayer's timing and expectations for collection management; and (4) association of the surrounding socioeconomic reality with the tax structure.

\subsection{Skewed costs and benefits perception}

According to Mill's Principles of Political Economy (1848), "If all taxes were direct, taxation would be much more perceived than it is, and there would be a certainty that taxpayers don't now have".

This source of fiscal illusion exists because taxing authorities may prefer purchase taxes when they need to increase tax revenue, as they do not generate such a highly perceived tax burden for the taxpayer (Buchanan, 1960).

Fiscal illusion can also make elected politicians opt for excessively large public programs, causing voters to make mistakes in valuing the benefits and costs of public programs (Oates, 1985).

\subsection{Unawareness and inattention to tax reality}

In most democratic countries, taxpayers are likely to miss information on which to base their decisions regarding the assessment of public sector activities. This is mainly because the motivation to obtain information about the benefits and costs of government programs is much lower than that of private goods (Downs, 1960). Individuals determine their own preference for standards and choices regarding spending and consumption of private goods, and little time is spent understanding government programs. Fiscal illusion, especially in democratic countries, exists because of this unawareness of politics by voters and taxpayers (Downs, 1960).

\subsection{Managing the momentum and expectations of taxpayers}

Puviani (1903) devoted several paragraphs to the importance of managing the moment to collect taxes. Basically, he argued that taxpayers are less averse to paying taxes when they are motivated to do so, when they are in a good phase of their life or their business cycle, or when they perceive a greater expected advantage. Also, in managing the collection moment, the relevance of political discourse or a shift in public opinion are not indifferent as they may also reduce taxpayers' resistance to new taxes (Tanzi, 2011).

\subsection{Determination of the surrounding socioeconomic reality}

Many of the contributing voters, in turn, have scarce resources, low education, and a severe fiscal strain. This means that the effectiveness of fiscal illusion practices tends to be greater in communities with more unfavorable socioeconomic conditions. Consequently, there is also a tendency for higher 
public spending to occur, including the capture of opportunistic rents by local politicians, bureaucrats, and elite citizens (Bardhan \& Mookherjee, 2005). According to Fischer, Wartick and Mark (1992), the attitude toward and perception of taxes directly influence the behavior of tax compliance, while demographic factors are indirectly influential.

\section{Analysis of fiscal illusion in a sample of the Northern Portuguese population: Conception, pre-tests, distribution and results}

The first version of the questionnaire was divided into two parts: respecting literature on both the fiscal illusion measured by questionnaires (Costa, 2017; Oberholzer, 2007; Sausgruber \& Tyran, 2005) and the literature on questionnaire construction (Huot, 1992; Tremblay, 1991). In the first part, we asked taxpayers about their sociodemographic status -gender, age, level of education, and income level- to ascertain whether the perception of illusion depends on such variables, as stated in the literature review by Robbins (2001) or Oberholzer (2007). In the second part, we asked questions to test our assumptions, focusing on respondents' perceptions of taxes and their rates. Thus, in addition to the influence of specific literature focused on the fiscal illusion -especially from the writings of Buchanan (1960), Fasiani (1949), and Puviani (1903)- we also relied on the literature on surveys and questionnaires made to taxpayers or focused on fiscal reality (Heyndels \& Schmölders, 1995; Oberholzer, 2007; Sausgruber \& Tyran, 2005).

We followed Tremblay (1991) in the random placement of questions throughout the questionnaire to avoid biasing responses by serial correlation. Here are the questions relating to each of the four key structural areas for fiscal illusion (the respective number of the question appears after \#):

1. To study the bias in taxpayers' perception of the costs and benefits of public programs, we asked the following three questions:

\#11. Do you believe that the behavior of taxpayers in tax collection control would change if the taxes or other taxes that are paid in these consumer transactions (product purchases, services) were collected separately?

\#13. Do you think you pay more in excise or in income taxes?

\#23. Do you think what you pay in taxes equals what you get from the state?

2. To study the unawareness and distraction about the fiscal reality, we asked the following questions:

\#7. What are the top five taxes you know?

\#8. How much is the tax rate on a coffee in a restaurant?

\#9. How much is the tax rate on a soda in a restaurant?

$\# 10$. Have you seen any invoices that show the amount of taxes paid on the purchase of a product or the provision of a service?

\#12. Do you know how much you pay in taxes monthly?

\#15.If you have your own car, do you know how much you pay in fuel taxes per month?

\#16.If you have your own car, do you know how much you pay for the Single Road Tax?

\#17.If you own a property, do you know how much you pay for property taxes?

\#20. Do you know the amount of tax charged on soft drinks?

3. In order to study the use of the taxpayer's timing and expectations for tax collection, we prepared the following questions:

\#5. How much would the taxpayer prefer to pay under different circumstances?

\#6. If you had to pay 50 euros, what would be the preferred destination of the paid amount?

\#17. In your opinion, if there is a budget surplus, what need should this "margin" be applied to?

\#18. How would you characterize the tax burden in Portugal? 
\#20. How would you characterize the time required to fulfill your tax obligations?

\#21. Regarding fiscal stability (i.e., the volume of tax changes), how stable would you say Portugal is fiscally?

\#22. Which do you think would be the most important measure to improve the tax system in Portugal?

4. To better understand the association of the surrounding socioeconomic reality with the tax structure, we also added the following control issues:

\#14. Do you have your own car?

\#15. Do you own any property?

\#16. Do you consume sodas?

The questionnaire was distributed between January 2019 and May 2019. It was decided to perform a pre-test that consisted of the original survey's distribution to 15 respondents. Responses were evaluated in terms of diversity and statistical significance of diversity (through F-tests), as suggested by Huot (1992). Given the values obtained, changes made were to three questions (\#4, \#5, and \#6). The wording of these questions has been adjusted to achieve the purposes of clarity that the preliminary results indicated were missing.

Subsequently, surveys were distributed on paper and in digital format to collect more responses. The paper distribution was carried out in the 86 municipalities of the NUT2 region of northern Portugal. For the distribution of the questionnaire in digital format, we used the social network of Facebook as well as general emails from several universities located in northern Portugal. All the steps behind this data collection and management followed the Data Protection Regulation for European institutions.

The final database consisted of 349 answered surveys. Through the digital format, 241 questionnaires were collected, with the remaining 108 answers being obtained through the paper format. The average margin of error of this sample for most distributed questions is $5.2 \%$. These are the main characteristics of the surveyed sample (Tables 1, 2, 3 and 4) and the perceived dimensions of fiscal illusion according to the answers to the questions above.

Table 1. Distribution of the respondents by age (Question \#1)

\begin{tabular}{lc}
\hline Age & \\
\hline$<30 y r s$ & $66 \%$ \\
30yrs - 40yrs & $16 \%$ \\
40yrs - 50yrs & $10 \%$ \\
$>50 y r s$ & $7 \%$ \\
\hline
\end{tabular}

Source: own elaboration.

Table 2. Distribution of the respondents by gender (Question \#2)

\begin{tabular}{lc}
\hline Gender & \\
\hline Male & $37 \%$ \\
Female & $62 \%$ \\
N/A & $1 \%$ \\
\hline
\end{tabular}

Source: own elaboration. 
It can be seen that $66 \%$ of respondents were under 30 years of age, followed by the 30 - to 40 -yearold age group, which accounted for $16 \%$ of the surveys obtained. On a smaller scale, only $10 \%$ of the data was obtained from those aged between 41 and 50 years old. Finally, only $7 \%$ of the answers were obtained from those over 50 years of age. Additionally, 1\% of the respondents chose not to answer this question.

Notwithstanding, according to the respondents' gender, $62 \%$ of the survey sample were female and only $37 \%$ were male Once again, $1 \%$ of respondents did not answer this question.

Table 3. Distribution of respondents by educational level achieved (Question \#3)

\begin{tabular}{lc}
\hline School level & \\
\hline Primary school & $9 \%$ \\
Secondary school & $11 \%$ \\
Techno-Prof & $3 \%$ \\
Graduate & $32 \%$ \\
Post-grad & $5 \%$ \\
Master & $37 \%$ \\
PhD & $3 \%$ \\
\hline
\end{tabular}

Source: own elaboration.

Regarding the level of education achieved by the respondents, the largest share of the sample had reached, at least, graduation level.

While those who hold a Master's degree represent $37 \%$ of respondents, people that held an undergraduate education represent $32 \%$ of the sample. They are followed by $11 \%$ with a secondary education certificate, $6 \%$ with a basic education, $5 \%$ with some postgraduate education, and finally $3 \%$ with a PhD. We must also note that $5 \%$ of respondents did not answer this question.

Analyzing the answers to Question \#4, we can see that approximately half of the sample had no stable income. They are followed by a much lower share of just $14 \%$ with income ranging between 600 and 800 euros, followed by two groups of $10 \%$ each with incomes between 400 and 600 euros and with incomes between 800 and 1000 euros. A smaller group of $8 \%$ had incomes between 1000 and 1500 euros and two groups of 4\% each had incomes lower than 400 euros and incomes above 1500 euros.

Table 4. Distribution of respondents by monthly income (Question \#4)

\begin{tabular}{lc}
\hline Monthly income & \\
\hline No income & $45 \%$ \\
$<400 €$ & $4.3 \%$ \\
$400 €-600 €$ & $10 \%$ \\
$600 €-800 €$ & $14 \%$ \\
$800 €-1000 €$ & $10 \%$ \\
$1000 €-1500 €$ & $8 \%$ \\
$>1500 €$ & $3.7 \%$ \\
N/A & $5 \%$ \\
\hline
\end{tabular}

Source: own elaboration. 
From this question onward, we will display the most specific questions addressing the effects of fiscal illusion dimensions limited to this survey sample.

The next answers are associated with this tax psychology question (Question \#5), in which the taxpayer assumes a preference of 'winning' something after 'paying' or 'losing' a certain amount (Fasiani, 1949).

According to the survey, "Paying 200 euros after receiving the news that you have won a home is preferred by $61 \%$ of respondents, which demonstrates their desire to obtain a home in the future even while expecting to pay a tax burden (albeit relatively small). These answers are consistent with those discussed by Puviani (1903) and Fasiani (1949); these authors had already mentioned the illusory effect of paying too many taxes after being anesthetized by receiving a public allowance/gain or after a personal achievement.

Table 5. Distribution of answers about preferred tax value discounted by an award or punishment (Question \#5)

\begin{tabular}{ll}
\hline Preferences for paying... \\
\hline $200 €$ after winning a house & $61 \%$ \\
$50 €$ after winning a car & $19 \%$ \\
$200 €$ after completing a PhD & $11 \%$ \\
$20 €$ after losing your wallet & $7 \%$ \\
\hline
\end{tabular}

Source: own elaboration.

Table 6 refers the distribution of the responses related to the preferences for the destination of a paid amount of 50 euros in taxes (Question \#6).

Table 6. Distribution of the responses related to the preferences for the destination of a paid amount of 50 euros in taxes (Question \#6)

\begin{tabular}{lc}
\hline Having paid a tax of 50€, you'd prefer & \\
\hline Reduction of costs of public services & $40 \%$ \\
Detailed information about tax revenue destinations & $30 \%$ \\
A rise in Portuguese GDP & $18 \%$ \\
Other preferences: reduction of public debt interest; & $5 \%$ \\
investment in social infrastructure; investment in & \\
education, health and sports; debt reduction; oil discount & $7 \%$ \\
N/A & \\
\hline
\end{tabular}

Source: own elaboration.

These results agree with a study by the OECD (2019) revealing the areas mostly considered a priority for the Portuguese. These areas have been found to be health care and retirement pensions. In this same study, Portugal was the second country where people were most receptive to tax increases to finance more social spending (behind only Ireland). We decided to quantify the number of times each of the mentioned taxes was reported by each respondent (Figure 1), observing the distribution of the answers to question 7.

This allows us to ascertain that the best-known tax is undoubtedly VAT (in Portugal, IVA). Some 276 of 349 respondents mentioned VAT as a known tax, followed by the IRS with 248 mentions, IMI 
with 238, IRC with 196, and IUC with 140. Less well-known taxes include IS with 53 mentions, IMT with 41, ISP with 33 , ISV * (IA + ISV) with 28, IT and TSU with 8, Derrama with 5, IABA with 3 responses, and IC, CA, IEC and IV with just 1 response each. For this question, 54 respondents did not answer.

Figure 2 describes the responses we obtained regarding the knowledge of the tax rate on a coffee.

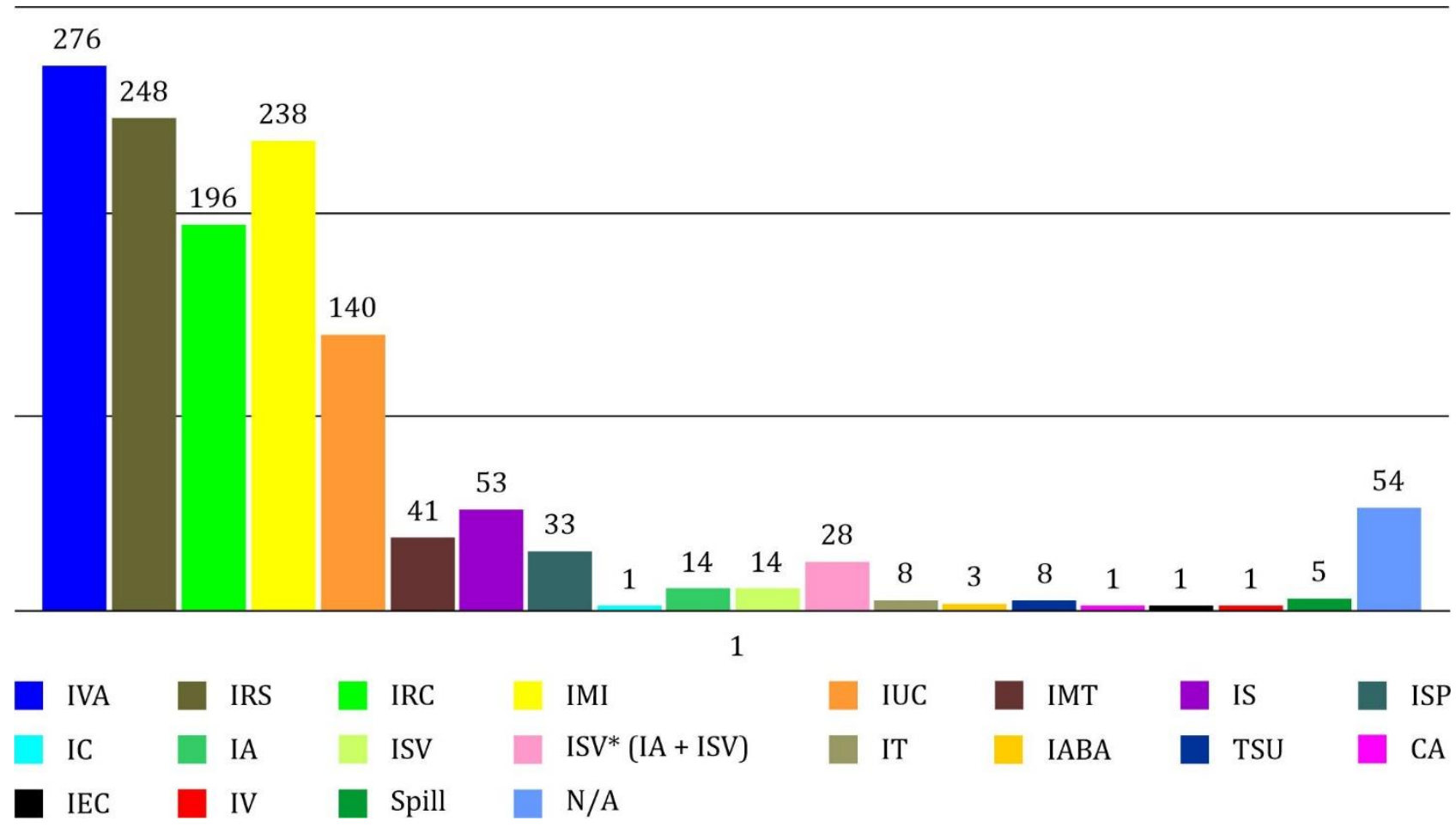

Figure 1. The five best-known taxes (Question \#7). Legend: VAT (IVA); Income Tax (IRS); Real Estate Tax (IMI); Firms Profit Tax; Car Tax; Stamp Tax; House Acquis. Tax (IMT); Oil Tax (ISP); ISV; Municipal Tax on Firms (Derrama). Source: own elaboration.

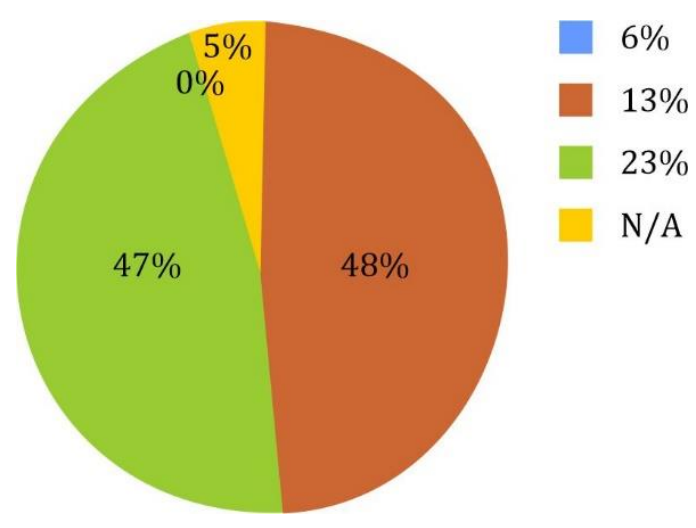

Figure 2. Tax rate on a coffee (Question \#8). Source: own elaboration.

Given this information, the correct answer was only selected by $42 \%$ of respondents, while $54 \%$ of respondents made a mistake $(40 \%$ of respondents answered at a rate of $23 \%$ and $14 \%$ of respondents 
answered $6 \%$ tax. In this question, $4 \%$ percent of respondents (14 of 349) did not answer. Thus, we can recognize a significant unawareness of the taxpayers regarding this tax , in particular.

Figure 3 relates to the knowledge of the tax rate on 1 kilogram of apples.

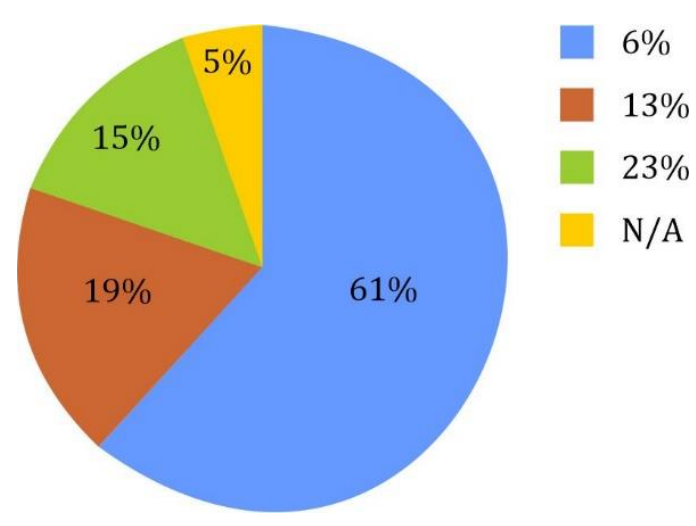

Figure 3. Tax rate on $1 \mathrm{~kg}$ of apples (Question \#9). Source: own elaboration.

In the question about the value added tax rate applied to a product considered essential, the correct $6 \%$ option was the dominant one. The correct option garnered a significant majority of $61 \%$ of respondents ( 215 of 349 ).

Question \#10's responses led us to the distribution of the responses in Figure 4.

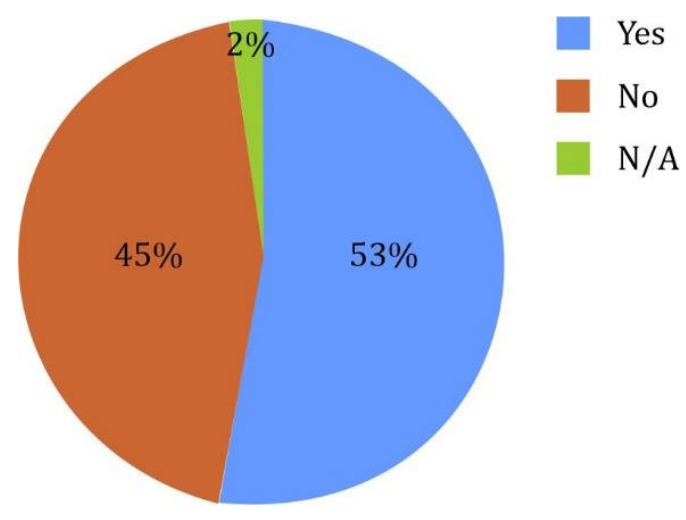

Figure 4. Have you ever seen an invoice showing the tax rates on the acquired product or service? (Question \#10). Source: own elaboration.

Regarding this issue (with a margin of error of 5.2 percentage points), we note that the majority, although not significant, of $53 \%$ of respondents have observed that taxes are included on the goods and services purchased (187 of 349). However, $45 \%$ of respondents have never noticed these fiscal details on invoices (156 of 349). $2 \%$ (6 of 349 respondents) did not answer this question.

Table 7 describes the distribution of the responses we obtained regarding the perception of respondents related to the possible change of people realizing taxes are embodied (or not) in the final prices of the acquired goods and services.

In question \#11, we asked respondents whether they consider taxpayers' behavior would change if taxes on goods and services were collected separately as in other countries. 
We obtained roughly equal percentages of $42 \%$ of Yes and Maybe. This strong response suggests that taxpayers being taxed separately of the acquisition act would react differently and thus become more aware of how much they pay in taxes, thereby lowering the level of fiscal illusion. Only a small portion of $14 \%$ of respondents think that way taxes are applied would not affect taxpayers' behavior

Table 7. Do you think that taxpayers' behavior would change if taxes were not included in final prices? (Question \#11)

\begin{tabular}{lc}
\hline Answers & \\
\hline Yes & $42 \%$ \\
No & $14 \%$ \\
Maybe & $42 \%$ \\
N/A & $2 \%$ \\
\hline
\end{tabular}

Source: own elaboration.

From this question we can clearly see that most taxpayers are unaware of how much they pay in taxes per month.

This evidence is represented here by a very high percentage $(81 \%)$ who do not know how much they pay in taxes. Only 18\% know how much they pay in taxes per month. Recalling again that the margin of error of this sample is 5.2 percent points, we can safely say that the Portuguese do not know how much they pay in taxes every month.

A Pearson chi-squared test was performed to evaluate the independence of the answers to Question \#12 and the answers related to the education level of respondents as shown in Table 3. The obtained value (Pearson chi-squared $(7)=6,224 ; p$-value $=0.514$ ) allows us to accept the hypothesis of independence between the answers to these questions, showing that, for the sample consulted, the argument that a more qualified population assumes a better knowledge of the tax level did not hold true. Pearson's chi-squared test to assess the independence of the answers to Question \#12 and the answers regarding the level of income already yielded a distinct reading. In this case, we reject, at a level of $10 \%$ (Pearson chi-squared $(6)=11.61$ ), the independence hypothesis and thus consider that knowledge of the tax level depends on the respondent's monthly income. These results validate the statements by Ferreira (2013), Robbins (2001), and Oberholzer (2007) that perceptions of fiscal illusion are particularly influenced by the characteristics of the individual's economic situation.

Table 8. Do you know how much you pay every month for taxes? (Question \#12)

\begin{tabular}{lc}
\hline Answers & \\
\hline Yes & $18 \%$ \\
No & $81 \%$ \\
N/A & $1 \%$ \\
\hline
\end{tabular}

Source: own elaboration.

In Table 9, which reflects the questions given to question \#13 (perception of paying more in excise or income taxes), we find that respondents are also aware of these developments, thus revealing a majority share of $77 \%$ (269 in 349) who claim to pay more in indirect taxes (consumption taxes). 
Table 9. Do you pay more for taxes on consumption or on income? (Question \#13)

\begin{tabular}{lc}
\hline $\begin{array}{l}\text { Do you pay more for taxes on consumption } \\
\text { or on income? }\end{array}$ \\
\hline More on taxes on consumption & $77 \%$ \\
More on income taxes & $20 \%$ \\
N/A & $3 \%$ \\
\hline
\end{tabular}

Source: own elaboration.

A minority of only $20 \%$ claim to pay more in direct taxes (income taxes). Again, $3 \%$ of respondents chose not to answer this question.

In the next tables, we can reflect on the knowledge of taxation associated with car ownership and use.

Some $56 \%$ of respondents own their own car, in contrast to $43 \%$ who do not.

Table 10. Do you own a car? (Question \#14)

\begin{tabular}{lc}
\hline Do you own a car? & \\
\hline Yes & $56 \%$ \\
No & $43 \%$ \\
N/A & $1 \%$ \\
\hline
\end{tabular}

Source: own elaboration.

In Table 11, we see a significant portion of $72 \%$ said they do not know how much they pay for fuel taxes per month, and only 14\% (48 of 349) say they know how much they pay for taxes on fuel monthly. This result is also important, as it demonstrates the lack of interest or lack of knowledge about fuel taxes, which is consistent with the above literature.

Table 11. Do you know how much you pay for oil taxes? (Question \#15)

\begin{tabular}{ll}
\hline $\begin{array}{l}\text { Do you know how much you } \\
\text { pay for oil taxes? }\end{array}$ \\
\hline Yes & $14 \%$ \\
No & $72 \%$ \\
N $/ A$ & $14 \%$ \\
\hline
\end{tabular}

Source: own elaboration.

According to the European Automobile Manufacturers Association (ACEA, 2019), in January 2019, a litre of diesel cost 1.32 euros in Portugal. However, the same litre of diesel without any taxes and fees had a value of only 0.59 euros. For 95 octane petrol, the cost of a litre was 1.41 euros, but the same amount before VAT, ISP, road tax and carbon tax surcharge was only 0.51 euros per liter. Therefore, despite the significant weight of oil taxes in Portugal, Portuguese drivers manifest a significant lack of knowledge about this tax issue. 
Table 12. If you answered 'Yes' to Question \#15, how much do you pay)

\begin{tabular}{ll}
\hline $\begin{array}{l}\text { If your previous answer was 'Yes', } \\
\text { how much do you pay in oil taxes? }\end{array}$ \\
\hline Several numerical answers & $13 \%$ \\
N/A & $87 \%$ \\
\hline
\end{tabular}

Source: own elaboration.

Observing Table 13, we confirm that almost half of the respondents do not know how much they pay for the single road tax: 49\% (172 of 349 respondents). Only 36\% of respondents (126 of 349) demonstrate awareness of how much they pay for this tax. For this question, a high percentage of $15 \%$ of respondents ( 51 of 349) chose not to answer this question.

Table 13. Do you know how much you pay for the single road tax? (Question \#16)

\begin{tabular}{ll}
\hline $\begin{array}{l}\text { Do you know how much you pay for } \\
\text { the single road tax? }\end{array}$ \\
\hline Yes & $36 \%$ \\
No & $49 \%$ \\
N/A & $15 \%$ \\
\hline
\end{tabular}

Source: own elaboration.

This open-ended question obtained a $66 \%$ abstention rate. However, the number of answers increased significantly, compared to the number of answers to the previous open answers to $34 \%$. It is noted here that 9 respondents who, in the previous question, assured us that they knew how much they paid for IUC, did not reveal the value in this open response.

Table 14. If you answered 'Yes' to Question \#16, how much do you pay for the single road tax?

\begin{tabular}{ll}
\hline $\begin{array}{l}\text { If your previous answer was 'Yes', how } \\
\text { much? }\end{array}$ \\
\hline Several numerical answers \\
N/A & $34 \%$ \\
\hline
\end{tabular}

Source: own elaboration.

In the next 3 Tables we analyze the relation between house ownership and related tax perception.

In this question, we observe that the vast majority -corresponding to $75 \%$ of respondents- do not own any property, which correlates with the majority of the surveyed population being under 30 years of age. Older people tend to value more the redistributive role of the public sector, especially via pensions. On the other hand, they have a greater knowledge and perspective of the activities carried out by the public sector. Therefore, the evidence of the answers to the previous question also highlight the concentration of our respondents in the younger cohorts. 
Table 15. Do you own a house? (Question \#17)

\begin{tabular}{lc}
\hline Do you own a house? & \\
\hline Yes & $23 \%$ \\
No & $75 \%$ \\
N/A & $2 \%$ \\
\hline
\end{tabular}

Source: own elaboration.

Given this information, we can see that $23 \%$ of respondents reported that they owned some estate property, but only $19 \%$ know how much they pay for IMP. We also observed that $37 \%$ of respondents do not know how much they pay for IMI and that $44 \%$ of respondents did not answer this question. We can also see that 15 people who own a property do not know how much they pay for IMI and the others do not know or did not respond.

Table 16. If you answered 'Yes' to Question \#17, do you know how much Real Estate Tax you pay annually? (Question \#18)

\begin{tabular}{ll}
\hline $\begin{array}{l}\text { If your previous answer was 'Yes', do } \\
\text { you know how much Real Estate Tax } \\
\text { you pay? }\end{array}$ \\
\hline Yes & $19 \%$ \\
No & $37 \%$ \\
N/A & $44 \%$ \\
\hline
\end{tabular}

Source: own elaboration.

In this question, we can see a high percentage of ( $81 \%$ ) of respondents (284 of 349) did not answer this question because either they do not own any property or they do but do not know the amount of IMI imposed on them. We also found that the percentage of concrete responses also remained at $19 \%$ (this information will be made available if required).

Table 17. If you answered 'Yes' to Question \#18, approximately how much do you pay?

\begin{tabular}{ll}
\hline $\begin{array}{l}\text { If your previous answer was 'Yes', } \\
\text { approximately how much do you pay? }\end{array}$ \\
\hline Several numerical answers & $19 \%$ \\
N/A & $81 \%$ \\
\hline
\end{tabular}

Source: own elaboration.

Following the literature on "paired tax knowledge" (i.e., there tends to be greater knowledge of a particular tax subject if the taxpayer also knows another tax subject), in line with White, Curatola and Samson (1990), Mei Lin and Chin-Fatt (2000) and Palil (2005), we have appreciated at the correlation between the answers to the two questions (IUC and IMI). The independence test returned a $p$-value of 0.000 (Pearson chi-squared $(1)=22.377$ ) which allows us to conclude that there is a strong likelihood 
of association in answering IUC knowledge questions (questions \#15 and \#16) and about IMI (questions \#17 and \#18). Therefore, we can conclude that a more tax-informed taxpayer is more likely to be aware of any other existing tax.

The next two questions are related to the sample's perception about excise taxes such as those that affect the consumption of sugary drinks.

In Portugal, a 'Sugar Tax' was introduced in 2017. The Sugar Tax was aimed at reducing the excessive consumption of sugar by the Portuguese population. Currently, the Excise Code (IEC) provides that beverages with a sugar content of fewer than 80 grams per liter are subject to a tax of EUR 8.22 per 100 litres, while those in which the sugar content exceeds 80 grams per litre are taxed at 16.69 euros per 100 litres. The aim was to reduce the sugar consumption induced by the decrease in the consumption of these beverages, either as a result of the price increase of these products or the possible reputational effects, as well as the decrease in sugar consumption induced by the reformulation of the sugar content of these beverages. However, as reported by Vito Tanzi (2011), excise taxes can also be related to the fiscal illusion effect as governments can use the changes in public opinion that reduce taxpayers' resistance to new or additional taxes. People can easily accept an over taxation on this kind of product as a response to a health issue.

Looking at Tables 18 and 19, we can see that, although consumers of soft drinks represent a share of $61 \%$, only $47 \%$ of them claim to know the amount of tax on soft drinks. A majority of $51 \%$ is unaware of the amount of tax included. The remaining $2 \%$ did not answer this question.

Table 18. Do you drink soda? (Question \#19)

\begin{tabular}{lc}
\hline Do you drink soda? & \\
\hline Yes & $61 \%$ \\
No & $38 \%$ \\
N/A & $1 \%$ \\
\hline
\end{tabular}

Source: own elaboration.

Table 19. Do you know about the tax on soda? (Question \#20)

\begin{tabular}{lc}
\hline Do you know the tax on soda? & \\
\hline Yes & $47 \%$ \\
No & $51 \%$ \\
N/A & $2 \%$ \\
\hline
\end{tabular}

Source: own elaboration.

In the next table, we show the distribution of respondents according to their opinion about political policies that should be taken if there is a budget surplus. To answer this question, respondents could choose more than one option.

The results for Table 20 converge with results achieved by Ferreira (2013) for a sample of Portuguese people and by Hammar, Jagers and Nordblom (2008) for a Swedish company. These studies also recognized a preference for tax reduction, given the high level of taxation, and that this preference will be more recorded in the taxes to which the respondent is being subjected. In our study, it was found that a share of 39\% (135 of 349 respondents) wished for a reduction in the tax burden on taxpayers, and that $29 \%$ of respondents (101 of 349) wished for a faster reduction of public deficit and public debt. OECD (2019) stated that the Portuguese answered they would not mind paying more 
taxes if tax revenues were redistributed to higher spending on the public system that encompasses both health and education, which also meets these results. Around $21 \%$ of respondents wished for increased spending on public health and $9 \%$ wished for increased spending by the state on education. Analyzing the combined answers, the most frequent was the "tax burden reduction" plus "health expenditure increase" and, less often, the combination of the expenditure increase in health and education.

Table 20. In your opinion, if there is a budget surplus, which political measure can follow? (Question \#21)

\begin{tabular}{ll}
\hline $\begin{array}{l}\text { In your opinion, if there is a budget surplus, which measure } \\
\text { can follow? }\end{array}$ \\
\hline A reduction of tax charge & $39 \%$ \\
A faster reduction of structural deficit and of public debt & $29 \%$ \\
Higher expenses for public health & $21 \%$ \\
Higher expenses for education & $9 \%$ \\
N/A & $1 \%$ \\
\hline
\end{tabular}

Source: own elaboration.

The following question, recalling the margin of error of 5.2 percentage points, asked the opinion of the respondents regarding the perceived weight of the tax burden in Portugal.

According to the National Institute of Statistics of Portugal (2019), the tax burden registered in Portugal reached its highest value in 2018 since, at least ,1995, exceeding the previous peak reached in 2017. The amount of taxes and contributions delivered by the Portuguese to the state in 2018 reached $35.4 \%$ of GDP. According to our survey, the largest share corresponding to $45 \%$ of respondents consider the tax burden applied in Portugal to be high, $25 \%$ consider the tax burden to be intermediate, $23 \%$ consider the tax burden to be very high. Only $2 \%$ of respondents consider the tax burden low and only $1 \%$ consider the tax burden in Portugal to be very low. Just $4 \%$ of respondents did not answer this question.

By performing an independence test between the answers to Question \#21 and the respondents' educational level, we can reject the null hypothesis (non-association) at a p-value of less than $1 \%$ (Pearson chi-squared $(35)=87,965)$. These results converge with those suggested by Blaufus et al. (2015), who, reviewing Schmölders' conclusions, analyzed the German population's perception of marginal income tax rates. One of the survey's results also pointed to a positive relationship between the interviewee's educational level and their perception of the tax burden, so that the higher the educational level, the more accurate tax perception is.

Table 21. How do you characterize the tax charge in Portugal? (Question \#22)

\begin{tabular}{lc}
\hline $\begin{array}{l}\text { How do you characterize the tax charge } \\
\text { in Portugal? }\end{array}$ \\
\hline Very low & $1 \%$ \\
Low & $2 \%$ \\
Intermediary & $25 \%$ \\
High & $45 \%$ \\
Very high & $23 \%$ \\
\hline
\end{tabular}

Source: own elaboration. 
By performing an alternative independence test between the answers to Question \#25 and the respondent's level of education or income level, we can reject the null hypothesis (non-association) at a $p$-value of less than $10 \%$ and $1 \%$, respectively. The respective values are Pearson chi-squared (28) = 39,342; and Pearson chi-squared $(24)=46,051$. These results converge with those suggested by Ferreira (2013), Robbins (2001), and Oberholzer (2007) who demonstrated an association between educational level or income level and a different perception of the tax burden.

In the next question we wanted to find out if taxpayers are satisfied with what they pay compared to what they receive from the state.

Table 22 shows that we obtained a significant majority of $55 \%$ of respondents who answered what is received from the state does not compensate for the taxes paid. Another $31 \%$ are undecided as to whether or not it really compensates for what is paid to the state over what is received from it, having chosen the "more or less" option, and only $11 \%$ state that what is received really compensates for what they pay. Still 3\% of respondents chose to remain on the sidelines. With these answers, we can see that taxpayers feel very dissatisfied with what they receive from the state, compared to what they pay to it, in line with the studies by Eriksen and Fallan (1996).

Table 22. Do you think the benefits you receive compensate for the amount you pay for taxes? (Question \#23)

\begin{tabular}{lc}
\hline Answer & \\
\hline Yes & $11 \%$ \\
No & $55 \%$ \\
More or less & $31 \%$ \\
N/A & $3 \%$ \\
\hline
\end{tabular}

Source: own elaboration.

According to Wagner (1976) and Heyndels and Smolders (1995) the complexity of the revenue can influence the taxpayer's perceptions of the cost of government. To analyze this complexity, we asked our survey sample about their time perception to calculate and pay taxes.

From Table 23, we found that a majority of 53\% of respondents stated that the required time is intermediate. Some $17 \%$ of respondents say that the time required to comply with tax obligations is short. In contrast, $16 \%$ refer to the time required as long, $5 \%$ consider the time required to be very long, while $3 \%$ say the time required is too short. We can thus note that there is a dispersion of answers. Finally, 6\% chose not to answer this question.

Table 23. How do you characterize the time you spend paying taxes and other tax duties? (Question \#24)

\begin{tabular}{lc}
\hline How do you characterize the time you \\
spend paying taxes and other tax duties? \\
\hline Very short & $9 \%$ \\
Short & $17 \%$ \\
Intermediate & $53 \%$ \\
Long & $16 \%$ \\
Very long & $5 \%$ \\
\hline
\end{tabular}

Source: own elaboration. 
Also, as mentioned above, a stable tax system can be related to the taxpayers' perception of the tax burden, as governments would not change the general tax laws frequently just because people became particularly insensitive to "old" taxes. So, in question \#25 we asked the opinion of the respondents regarding the fiscal stability (volume of tax changes) demonstrated in Portugal.

From Table 24, we found a dispersion of responses. The largest proportion of respondents (42\%) say that Portuguese fiscal stability is at an intermediate level, while 35\% say that there is some degree of fiscal instability in Portugal. A smaller group of $13 \%$ say that there is very high fiscal instability in Portugal, while $7 \%$ say there is fiscal stability in Portugal.

Table 24. How do you characterize the stability of changes in the Portuguese tax system? (Question \#25)

\begin{tabular}{ll}
\hline $\begin{array}{l}\text { How do you characterize the stability of } \\
\text { changes in the Portuguese tax system? }\end{array}$ \\
\hline Very unstable & $13 \%$ \\
Unstable & $35 \%$ \\
Intermediate & $42 \%$ \\
Stable & $7 \%$ \\
Very Stable & $3 \%$ \\
\hline
\end{tabular}

Source: own elaboration.

In line with Blaufus et al. (2015), we wanted to verify if there is an association of the answers to question \#25 and the level of education of respondents (question \#3). We could verify that they are not independent (at a level of $10 \%$ ), so we can say that awareness regarding the fiscal stability existing in our country does not depend on the level of education attained by the individual. Also, at the same level of significance (10\%), we observed that the hypothesis of independence between the answers to Question \#28 and the respondent's income level can be rejected (Pearson chi-squared (24) = 33,874, $p$-value $=0.087$, which reinforces the income dimension as particularly relevant for the tax perception of Portuguese taxpayers.

In question \#26 (Table 25), respondents were asked what they thought would be the best measure to improve the tax system in Portugal.

Table 25. Which would be the most important measure for improving the Portuguese tax system? (Question \#26)

\begin{tabular}{l} 
Which would be the most important measure for \\
improving the Portuguese tax system? \\
\hline Reduction of taxes \\
Fiscal transparency \\
Fiscal stability \\
Simplification of the tax system \\
N/A
\end{tabular}

Source: own elaboration.

Table 25 reveals that a very significant percentage of $46 \%$ believe that the most important measure would be greater tax transparency, while $23 \%$ consider tax reduction as the most important measure 
to improve the tax system in Portugal. Also, 18\% prefer tax simplification measures as the most important factor. Finally, 11\% consider fiscal stability to be a key element in improving the tax system (legislative instability in tax matters and the complexity of procedures are obstacles to economic activity in Portugal).

\section{Conclusion, implications and challenges}

This work represents the first effort, located in Portugal, to analyze the presence of fiscal illusion in the Portuguese population using four structural tendencies. To this end, a sample of the northern population of the country was surveyed by collecting data by distributing surveys. The results of the statistical treatment show that of the four dimensions pointed out by literature, the surveyed sample of the Portuguese population presents the dimension of fiscal inattention more severely, meaning that, in general, the surveyed sample revealed little attention to the fiscal reality, both in the relationship with the tax authorities and taxation associated with day-to-day actions. On closer examination, it has been found that this 'tax inattention' is not dissociated from certain respondent characteristics. Particularly, respondents with higher incomes tended to pay more attention to the fiscal reality that surrounds them; on the other hand, the schooling pattern was not so significant in explaining the diversity of reactions.

The remaining dimensions - the socioeconomic context, the use of taxpayer momentum, and the bias in the perception of the costs and benefits of public programs -although significant in the sample, were not of the same magnitude as fiscal inattention.

Some implications emerge from these results. The seriousness of the problem of fiscal inattention provides a necessary warning of a more effective fight so that taxpayers are able to collect better tax information, to reach a level of fuller intelligibility and comprehension and, finally, to realize the consequences of public finance decisions. Another implication concerns the concertation of the various actors on the ground for greater fiscal transparency (namely through the fiscal authority, but also citizens' associations and academies) so that the work -sometimes isolated- of each of these groups of actors leads to a more concerted and accomplished effort.

Being a pioneering work, this study poses several emerging challenges. The first challenge concerns the extension of the sampling exercise to extend it to the entire Portuguese population. Although results here focus on a specific region, results extended across the country could potentially offer a more detailed scope and highlight the differentiated profile in each region. A second challenge concerns the possibility of exploring experimental economics methods in order to verify the convergence/divergence with the results found here. Finally, and within the purview of several authors, fiscal illusion should be a phenomenon that does not disappear per se, but instead, finds new mechanisms and resources - notably those enabled by digital tools and associated rhythms that can create other focuses of fiscal inattention. These new digital threats and challenges take advantage of the taxpayer's momentum but they have not yet been properly discussed.

\section{References}

ACEA (2019). ACEA Tax Guide 2019. Brussels, Belgium: European Automobile Manufacturers Association. Recuperado de https://www.acea.be/uploads/news documents/ACEA Tax Guide 2019.pdf

Bardhan, P., \& Mookherjee, D. (2005). Decentralizing antipoverty program delivery in developing countries. Journal of Public Economics, 89(4), 675-704. DOI: https://doi.org/10.1016/j.jpubeco.2003.01.001

Blaufus, K., Bon, J., Hundsdoerfer, J., Sielaff, C., Kiesewetter, D., \& Weimann, J. (2015). Perception of income tax rates: evidence from Germany. European Journal of Law and Economics, 40, 457-478.

Brumby, J. (1999). Budgeting reforms in OECD member countries. In S. Schiavo Campo \& D. Tommasi, Managing government expenditure (pp. 486-508). Manila, Philippines: Asian Development Bank (ADB). Recuperado de https://www.adb.org/sites/default/files/publication/27901/managing-government-expenditure.pdf 
Buchanan, J. (1960). Fiscal theory and political economy. Durham, NC: University of North Carolina Press.

Christensen, A., Weihrich, S., \& Newman, M. (1994). The impact of education on perceptions of tax fairness. Advances in Taxation, 6, 63-94.

Costa, L. (2017). Literacia fiscal: Importância e perceção - Peniche. (Master Dissertation). Lisboa, Portugal: Instituto Superior de Economia e Gestão. Recuperado de https://comum.rcaap.pt/bitstream/10400.26/23044/1/LITERACIA\%20FISCAL\%20\%e2\%80\%93\%20IMP0 RT\%c3\%82NCIA\%20E\%20PERCE\%c3\%87\%c3\%830\%20\%e2\%80\%93\%20PENICHE.pdf

Da Empoli, D. (2002). The theory of fiscal illusion in a constitutional perspective. Public Finance Review, 30(5), 377-384. DOI: https://doi.org/10.1177/109114210203000504

Dell'Anno, R., \& Mourão, P. (2012). Fiscal illusion around the world: An analysis using the structural equation approach. Public Finance Review, 40(2), 270-299. DOI: https://doi.org/10.1177/1091142111425226

Direção Geral do Orçamento (DG0, 2017). Síntese de execução orçamental. Dezembro/2017. Lisboa, Portugal: DGO.

Dollery, B. E., \& Worthington, A. C. (1995). State expenditure and fiscal illusion in Australia: A test of the revenue complexity, revenue elasticity and flypaper hypotheses. Economic Analysis and Policy, 25(2), 125-140. D0I: https://doi.org/10.1016/S0313-5926(95)50021-9

Dollery, B. E., \& Worthington, A. C. (1996). The empirical analysis of fiscal illusion. Journal of Economic Surveys, 10(3), 261-297. DOI: https://doi.org/10.1111/j.1467-6419.1996.tb00014.x

Downs, A. (1960). Why the government budget is too small in a democracy. World Politics, 12(4), 541-563. DOI: https://doi.org/10.2307/2009337

Eriksen, K., \& Fallan, L. (1996). Tax knowledge and attitudes towards taxation; A report on a quasi-experiment. Journal of Economic Psychology, 17(3), 387-402. DOI: https://doi.org/10.1016/0167-4870(96)00015-3

Fasiani, M. (1949). Contributi di Pareto allascienzadellefinanze. Giornale degli Economisti e Annali di Economia, $8(3-4), 129-173$

Ferreira, A. P. (2013). Atitude e percepção dos impostos-o caso português. (Master Dissertation). Porto, Portugal: Universidade do Porto, Faculdade de Direito.

Recuperado de https://repositorio-aberto.up.pt/bitstream/10216/69842/2/25409.pdf

Fischer, C. M., Wartick, M., \& Mark, M. (1992). Detection probability and tax compliance: A review of the literature. Journal of Accounting Literature, 11(2),1-46.

Fochmann, M., \& Weimann, J. (2013): The effects of tax salience and tax experience on individual work efforts in a framed field experiment. FinanzArchiv/Public Finance Analysis, 69(4), 511-542. DOI: http://doi.org/10.1628/001522113X675692

Hammar, H., Jagers, S. \& Nordblom, K. (2008). Attitudes towards tax levels: A multi tax comparison. Fiscal Studies, 29(4), 523-543. DOI: http://doi.org/10.1111/j.1475-5890.2008.00084.x

Heyndels, B., \& Smolders, C. (1995). Tax complexity and fiscal illusion. Dordrecht, Netherlands: Kluwer Academic Press.

Huot, R. (1992). La pratique de recherche en sciences humaines. Boucherville, QC: Gaëtan Morin.

Jones, L. R., \& Thompson, F. (1999). Public management: Institutional renewal for the twenty first century. Stamford, CT: Elsevier JAI Press.

Klerman, D. (2017). Takings, fiscal illusion, and the median voter. Journal of Institutional and Theoretical Economics (JITE), 173(1), 71-76. DOI: http://doi.org/10.1628/093245616X14743741664872

Magee, S. P., Brock, W. A., \& Young, L. (1989). Black hole tariffs and endogenous policy theory. Cambridge University Press.

Malhotra, N. K. (2012). Pesquisa de marketing: Uma orientação aplicada. Bookman Editora.

McCulloch, J. (1845/1975). A treatise on the practical influence of taxation and the funding system. Edinburgh, Scotland: Scottish Academic Press and Holmes \& Meier.

Mei Tan, L., \& Chin-Fatt, C. (2000). The impact of tax knowledge on the perceptions of tax fairness \& attitudes towards compliance. Asian Review of Accounting, 8(1), 44-58. DOI: https://doi.org/10.1108/eb060720

Mill, J. S. (1848/1857). Principles of political economy with some of their applications to social philosophy. George Manchester, England: Routledge.

Mourão, P. (2008). Towards a Puviani’s fiscal illusion index. Hacienda Pública Española, 187(4), 49-86.

Mourão, P. (2010). Fiscal illusion causes fiscal delusion-Please be careful! In S. Tenereiro de Magalhães, H. Jahankhani \& A. G. Hessami (Eds.), Global Security, Safety, and Sustainability. ICGS3 2010. Communicacións in Computer and Information Science, 92 (pp. 232-237). Berlin and Heidelberg, Germany: Springer. Recuperado de https://link.springer.com/chapter/10.1007/978-3-642-15717-2 25 
Munley, V. G., \& Greene, K. V. (1978). Fiscal illusion, the nature of public goods and equation specification. Public Choice, 33(1), 95-100. D0I: http://doi.org/10.1007/BF00123948

Nabais, J. C. (2003). Direito fiscal, vol. 2. Coimbra, Portugal: Almedina.

National Institute of Statistics of Portugal (INE, 2019). Destaque - Contas nacionais trimestrais por setor institucional (4ํo trimestre de 2018). Lisboa, Portugal: INE.

Oates, W. E. (1985). On the nature and measurement of fiscal illusion: A survey. College Park, MD: Universiy of Maryland, Department of Economics.

Oates, W. E. (1988). On the nature and measurement of fiscal illusion: A survey. In G. Brennan, B. S. Crewel \& P. Groenwegen (Eds.), Taxation and fiscal federalism: Essays in Honour of Russell Mathews. Canberra, Australia: Australian National University Press

Oberholzer, R. (2007). Perceptions of taxation: A comparative study of different population groups in South Africa. (Doctoral Dissertation). Pretoria, South Africa: University of Pretoria.

OECD (2019). Risks that matter: Main findings from the 2018 OECD risks that matter survey. Paris, France: OECD. Recuperado de www.oecd.org/social/risks-that-matter.htm

Palil, M. R. (2005). Does tax knowledge matters in self-assessment systems? Evidence from Malaysian tax administrative. Journal of American Academy of Business, 6(2), 80-84.

Peacock, A. (1997). Public choice analysis in historical perspective. Cambridge, England: Cambridge University Press. DOI: https://doi.org/10.1017/CB09780511559532

Pommerehne, W. W., \& Schneider, F. (1978). Fiscal illusion, political institutions, and local public spending, Kyklos, 31(3), 381-408. DOI: https://doi.org/10.1111/j.1467-6435.1978.tb00648.x

Puviani, A. (1903). Teoria della illusione finanziaria. Palermo, Italy: Sanaron.

Ricardo, D. (1820/1951). Funding systems. In P. Sraffa (Ed.), The works and correspondences of David Ricardo, vol. 4, Pamphlets and papers 1815-1823. Cambridge, England: Cambridge University Press.

Robbins, S.P. (2001). Organisational behaviour. 9th ed. Upper Saddle River, NJ: Prentice Hall.

Sanandaji, T., \& Wallace, B. (2010). Fiscal illusion and fiscal obfuscation: An empirical study of tax perception in Sweden. IFN Working Paper No. 837. Stockholm, Sweden: Research Institute of Industrial Economics (IFN). DOI: http://dx.doi.org/10.2139/ssrn.1619268

Sausgruber, R., \& Tyran, J. R. (2005). Testing the Mill hypothesis of fiscal illusion. Public Choice, 122(2), 39-68. DOI: http://dx.doi.org/10.2139/ssrn.699962

Schmoelders, G. (1960). Das Irrationale in der öffentlichen Finanzwirtschaft. Hamburg, Germany: Rowohlt.

Sousa, R. A. S. (2016). A descentralização e as finanças públicas - Contributo da qualidade da governação. (Master Dissertation). Porto, Portugal: Universidade do Porto.

Stiglitz, J. (2015). Economics of the public sector. New York, NY: W. W. Norton.

Tanzi, V. (2011). Government versus markets: The changing economic role of the state. New York, NY: Cambridge University Press.

Tremblay, A. (1991). Sondages. Boucherville, QC: Gaëtan Morin.

Turnbull, G. K. (1998). The overspending and flypaper effects of fiscal illusion: Theory and empirical evidence. Journal of Urban Economics, 44(1), 1-26. DOI: https://doi.org/10.1006/juec.1997.2056

Varela, P. S., Martins, G. D., \& Fávero, L. P. L. (2010). Ineficiência do gasto público e ilusão fiscal: Uma avaliação do flypaper effect na atenção básica à saúde. IV Congresso ANPCONT. Anais, Natal, Brasil.

Vitorino, A. F. M. (2016). Ilusão fiscal: Uma análise comparativa para os países da UE. (Master Dissertation). Porto, Portugal: Universidade do Porto.

Wagner, R.E. (1976). Revenue structure, fiscal illusion and budgetary choice. Public Choice, 25, 45-46. DOI: http://doi.org/10.1007/BF01726330

Wang, X., \& Bohn, F. (2019). Pension reserve fund, political budget cycles and fiscal illusion. European Journal of Political Economy, 56, 62-73. DOI: https://doi.org/10.1016/j.ejpoleco.2018.07.002

White, R. A., Curatola, A. P., \& Samson, W. D. (1990). A behavioral study investigating the effect of knowledge of income tax laws and tax policy on individual perceptions of federal income tax fairness. Advances in Taxation, 3, 165-185.

Winter, S., \& Mouritzen, P. (2001). Why people want something for nothing: The role of asymmetric illusion. European Journal of Political Research, 39, 109-43. DOI: https://doi.org/10.1023/A:1007185029456 